\title{
Identification of Factors Associated with Prolonged Stay in the Intensive Care Unit
}

\section{Yoğun Bakım Ünitesinde Uzun Süre Kalış ile Illişkili Faktörlerin Belirlenmesi}

\author{
(D) Mehmet Süleyman Sabaz' ${ }^{1}$ (D) Sinan Aşar ${ }^{2}$ \\ ${ }^{1}$ Marmara University Pendik Training and Research Hospital, Cyinic of Anesthesiology and Reanimation, Division of Intensive Care, İstanbul, \\ Turkey \\ 2University of Health Sciences Turkey, Bakırköy Dr. Sadi Konuk Training and Research Hospital, Cyinic of Anesthesiology and Reanimation, \\ İstanbul, Turkey
}

\begin{abstract}
Objective: This study aimed to determine the factors associated with prolonged intensive care unit length of stay (ICU-LOS), which is increasingly common in ICU, and to evaluate its effect on patient outcomes.

Methods: This retrospective study was evaluated by obtaining data of 5,022 patients who were followed in the ICU of a tertiary education and research hospital between January 2014 and January 2021 and met the research criteria in electronic environment.

Results: Patients were divided into two groups as patients with ICU-LOS $<14$ days ( $n=4,083,81.3 \%$ ) and patients with ICU-LOS $\geq 14$ days $(\mathrm{n}=939,18.7 \%)$. Sepsis and pulmonary diseases were more common in the prolonged ICU-LOS group than in the non-prolonged ICU-LOS group $(p<0.05)$. While $61.8 \%(2,525)$ in the non-prolonged ICU-LOS group needed mechanical ventilator support, this rate increased to $97.4 \%$ (915) in the prolonged ICU-LOS group $(p<0.001)$. The duration of MV was higher in the prolonged ICU-LOS group [20.3 (14.9-29.2)] than in the non-prolonged ICU-LOS group [3.4 (1.7-6.2)] (p>0.001). Although 18.7\% of the patients had prolonged ICU-LOS, they consumed $66.3 \%$ and $59.7 \%$ of all mechanical ventilator days and ICU hospitalization days, respectively. ICU mortality was higher in the prolonged ICU-LOS group $(n=376 ; 40 \%)$ than in the non-prolonged ICU-LOS group $(n=1219 ; 29.9 \%)$. The development of acute kidney injury (odds ratio (OR): 1,$807 ; 95 \%$ confidence interval (Cl) 1,434-2,277), development of pressure sores (OR: 3,572; 95\% Cl: 2,663-4,792), total parenteral nutrition use (OR: 2,014; $95 \% \mathrm{Cl}: 1,639-2,475)$, increase in body mass index (OR: 1,015; 95\% Cl: 1.001-1.031), and mechanical power increase (OR: 1.041; $95 \% \mathrm{Cl}: 1.002-$ 1.082) were associated with prolonged ICU-LOS (OR: $1.015 ; 95 \% \mathrm{Cl}: 1.001-1.031)$.
\end{abstract}

Conclusion: Prolonged ICU-LOS is associated with increased costs, use of resources, and morbidity and mortality.

Keywords: Intensive care units, length of stay, mechanical ventilation, mortality

\section{öz}

Amaç: Bu araştırma yoğun bakım ünitesinde (YBÜ) gittikçe daha sık rastlanan uzamış YBÜ kalış süresi (YBÜ-LOS) ile ilişkili faktörleri belirlemek ve hasta sonuçlarına etkisini değerlendirmek amacı ile planlandı.

Gereç ve Yöntem: Bu retrospektif araştırma Ocak 2014- Ocak 2021 döneminde üçüncü düzey bir eğitim ve araştırma hastanesinin YBÜ'de takip edilen ve araştırma kriterlerini karşılayan 5.022 hastanın verileri elektronik ortamda elde edilerek değerlendirildi.

Bulgular: Araştırmaya dahil edilen hastalar YBÜ-LOS <14 gün olan $4.083(81,3)$ hasta ve YBÜ-LOS $\geq 14$ gün olan $939(18,7)$ hasta olacak şekilde iki gruba ayrıldı. Uzamış YBÜ-LOS grubunda sepsis ve pulmoner hastalıklar uzamamış YBÜ-LOS grubundan daha sık görüldü ( $<<0,05)$. Uzamamış YBÜ-LOS hastalarının \%61,8'i (2.525) mekanik ventilatör desteğine ihtiyaç duyarken bu oran uzamış YBÜ-LOS hastalarında \%97,4'e (915) yükseldi $(p<0,001)$. Mekanik ventilasyon süresi uzamış YBÜ-LOS hastalarında $[20,3(14,9-29,2)]$, uzamamış YBÜ-LOS hastalarına $[3,4(1,7-6,2)]$ göre daha yüksekti ( $p>0,001)$. Uzamış YBÜ-LOS hastalarının oranının \%18,7 olmasına rağmen tüm mekanik ventilatör günlerinin \%66,3'ünü ve tüm YBÜ yatış günlerinin \%59,7'sini işgal ettikleri saptandı. YBÜ mortalitesi uzamış YBÜ-LOS grubunda (376; \%40), uzamamış YBÜ-LOS grubuna göre (1.219; \%29,9) daha yüksek bulundu. YBÜ'de akut böbrek hasarı gelişmesinin [risk ornaı (OR): 1.807; güven aralığı (Cl): \%95 1.434-2.277],

Address for Correspondence: Mehmet Süleyman Sabaz, Marmara University Pendik Training and Research Hospital, Clinic of Anesthesiology and Reanimation, Division of Intensive Care, İstanbul, Turkey

Phone: +90 5064415710 E-mail: udmss_47@hotmail.com ORCID ID: orcid.org/0000-0001-7034-0391

Cite as: Sabaz MS, Aşar S. Identification of Factors Associated with Prolonged Stay in the Intensive Care Unit.

Med J Bakirkoy 2021;17:233-242

Received: 03.09.2021

Accepted: 15.09.2021 
University of Health Sciences Turkey, bası yarası gelişmesinin (OR: 3.572; Cl: \%95 2.663-4.792), TPN kullanımının (OR: 2.014; Cl: \%95: 1.6392.475) vucüt kitle indeksi artışın (OR: 1.015; Cl: \%95: 1.001-1.031) ve mechanical power artışının (OR: 1.041; Cl: \%95: 1.002-1.082) uzamış YBÜLOS ile ilişkili olduğu belirlendi (OR: 1.015; Cl: \%95: 1.001-1.031).

Sonuç: YBÜ uzun süre kalma, artan maliyet ve kaynak kullanımı ile ilişkilidir. Ek olarak hastaların morbidite ve mortalitesinin de artmasına neden olmaktadır.

Anahtar Kelimeler: Yoğun bakım üniteleri, kalış süresi, mekanik ventilasyon, mortalite

\section{INTRODUCTION}

The science of intensive care has developed significantly in the last decade, and emerging technological developments and new treatments have reduced the mortality rates in intensive care units (ICUs) (1). Increasing survival and aging population as a result of advances in the early management of critical illnesses have led to the formation of a patient profile that is increasingly encountered in the ICUs and requires prolonged ICU follow-up. The number of patients with this profile, who are dependent on a particular type of technology or medical care, is expected to increase in the coming years $(2,3)$.

There is no consensus on the definition of long-term intensive care. Different criteria have been used for its definition, and it has been variously defined as staying in the ICU for $>10$ days or $>21$ days (4-7). In a more recent study, ICU stay of at least 14 days was defined as a prolonged ICU length of stay (ICU-LOS) (6). Depending on the definition used, $4 \%-11 \%$ of patients admitted to the ICU have been determined to have a prolonged ICU-LOS (8-10). Patients with ICU-LOS $>14$ days use approximately half of all ICU hospitalization days and mechanical ventilation (MV) use days, although they constitute a small proportion of patients admitted in the ICU $(10,11)$. Prolonged ICU-LOS is associated with increased cost and resource use and may affect morbidity and mortality. Long-term ICU-LOS can adversely affect health by increasing the risk of infection, complications, and possibly mortality $(9,12)$. Operationally, it affects ICU bed availability and results in the cancellation of elective surgeries, leading to long waiting times (9). Bed waiting time is prolonged before admission to the ICU, a factor known to affect patient outcomes (13). Identifying patients at risk of long-term stay can assist ICU management and prevent ICU bed shortage.

In patients followed up in the ICU, prolonged LOS causes increased costs and resource use, as well as prolonged ICU waiting time. Therefore, early identification of patients at risk of prolonged ICU-LOS is important. This study aimed to determine the factors associated with prolonged ICU-LOS and to evaluate its effect on patient outcomes.

\section{METHODS}

\section{Data Center}

This study was performed retrospectively in the ICU of a third-level training and research hospital in Istanbul, the most populous city in Turkey. Consisting of 27 tertiary hospital beds, the ICU accepts an average of 1340 patients per year. The nurse-patient ratio in these ICUs, which is controlled by the clinical decision support system (CDSS) and where extracorporeal treatments (ECMO, hemodialysis, and plasmapheresis) can be applied, is 1:2.

When a patient is admitted to the ICU, the patient's identity information, anamnesis, and examination findings are recorded in the patient file created in CDSS. Information that requires dynamic measurement, such as urine output and glasgow coma scale (GCS), is recorded in the CDSS patient file at regular intervals by the patient's physician. Intensive care scores are calculated and recorded with the algorithms defined in CDSS, taking into account the worst values in the last $24 \mathrm{~h}$. In addition, all bedside monitor parameters, MV data, extracorporeal applications, laboratory test results, and dose information of all infusions administered for treatment are transmitted to the CDSS from the applied devices, thanks to the electronic ecosystem created during the patient's ICU follow-up. Thus, all patient data are collected in the patient file in CDSS.

\section{Data Collection}

Data of patients admitted to the ICU between January 2014 and January 2021 from the EMRall-QlinICUImd Soft Metavision CDSS database used in the ICU were obtained by using Structured Query Language queries. In addition to the patients' LOS in the ICU, demographic data, admission diagnoses, comorbid diseases, scores calculated in the ICU, blood gas and biochemical values, MV data, treatments, and interventions, developed complications, and mortality results were evaluated.

\section{Sample}

A total of 9,380 patients were admitted to the ICU during the research period, of which 4,358 did not meet the research and exclusion criteria. The remaining 5,022 patients constituted the study population (Figure 1).

In the present study, similar to the study by Zampieri et al. (6), a 14-day or longer stay in the ICU was considered 


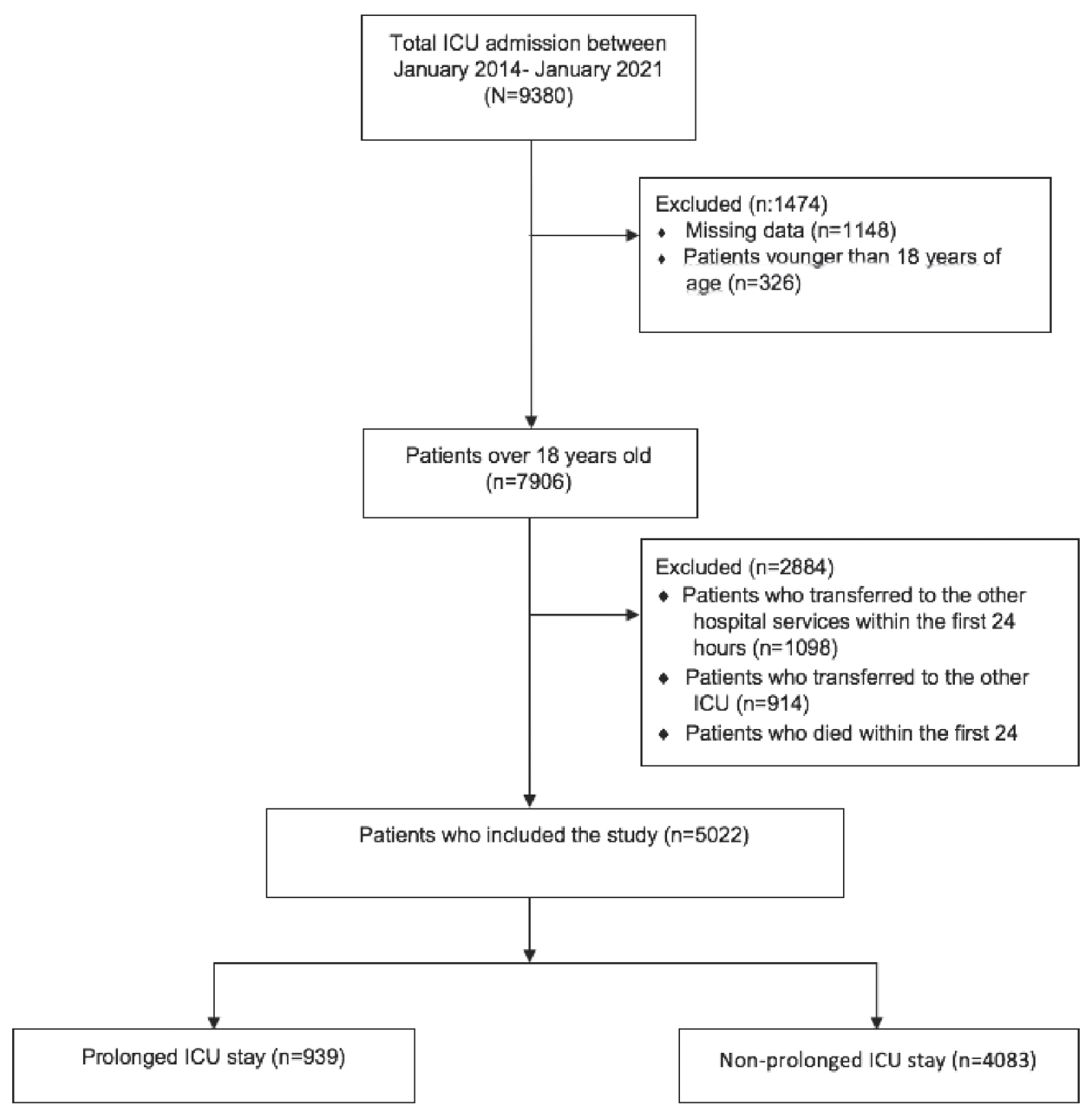

Figure 1. Flow diagram of patient selection

ICU: Intensive care unit

a prolonged ICU-LOS. Patients included in the study were divided into two groups: 4,083 (81.3) patients hospitalized for $<14$ days and 939 (18.7) patients with a hospitalization period of $\geq 14$ days.

\section{Admission Criteria}

The study planned to include the entire patient population aged $\geq 18$ years who stayed in the ICU for $>24 \mathrm{~h}$.

\section{Exclusion Criteria}

Patients aged $<18$ years $(n=326)$, admitted to the service within $24 \mathrm{~h}$ of ICU admission $(n=1,098)$, died within the first $24 \mathrm{~h}$ in the ICU $(n=872)$, referred to another ICU $(n=914)$, and had missing data $(n=1,148)$ were excluded from the study.

\section{Primary Outcome}

The primary outcomes were factors associated with prolonged hospital stay in the ICU and their effects on patient outcomes.

\section{Secondary Outcomes}

The secondary outcomes were comorbid diseases, admission diagnoses, scores, treatment, and interventions.

\section{Ethical Issues}

Before the study, ethical committee approval and institutional permission were obtained from the Clinical Research Ethics Committee (protocol code: 2021/405; decision no. 2021-16) of the public hospital where the study was conducted. 


\section{Statistical Analysis}

SPSS 22.00 program was used in the analysis of the research data. The Shapiro-Wilk test was used to determine the normal distribution of numerical data. Normally distributed numerical data were expressed as mean \pm standard deviation, and non-normally distributed numerical data were expressed as median and interquartile ranges. The independent samples t-test was used to compare the numerical data between groups, and the Mann-Whitney $U$ test was used when the conditions of this test were not met. Categorical variables were expressed as frequency and percentage. The chi-square test was used to compare categorical variables between groups, and Fisher's Exact test was used when the conditions of the chi-square test were not met. Logistic regression analysis was used to determine parameters associated with the risk of prolonged ICU hospitalization; $p<0.05$ was accepted for the significance level.

\section{RESULTS}

In this study, 56.9\% of the 5022 patients constituting the study population were male, and the mean age was $60.49 \pm 19.24$ years. The mean body mass index (BMI) was $27.11 \pm 5.58 \mathrm{~kg} / \mathrm{m}^{2}$. Moreover, $74.6 \%$ of the patients had at least one comorbid disease. The most common comorbid disease was hypertension $(n=1,835 ; 36.5 \%)$. Sepsis $(n=1,116$; $22.2 \%)$ was the most common admission diagnosis in the $I C U$, and $68.5 \%(n=3,440)$ of the patients with a calculated acute physiology and chronic health evaluation (APA-CHE) II score of 20 ( $n=1327)$ needed MV support. Acute kidney injury (AKI) was detected in 3,309 (65.8) patients. The median ICU-LOS of the patients was 4.54 (1.91-10.45) days. The ICU mortality rate was $31.7 \%(n=1595)$.

\section{Comparison of Groups in Terms of Clinical Characteristics}

Patients were divided into two groups as non-prolonged ICU-LOS group with $<14$ days and prolonged ICU-LOS group with $\geq 14$ days. While ICU-LOS was $<14$ days in 4,083 (81.3\%) of 5,022 patients, ICU-LOS was $\geq 14$ days in 939 patients (18.7). The general characteristics of the groups are given in Table 1. No significant difference was found in age and gender between the groups. The frequency of the male gender was higher in both groups. The frequency of comorbid disease was lower in the prolonged ICU-LOS group $(671 ; 71.5)$ than in the non-prolonged ICU-LOS group $(3,075 ; 75.3)(p<0.05)$. Hypertension was the most common comorbid disease in both groups. Considering other comorbidities, the frequency of chronic obstructive pulmonary disease (COPD), malignancies, and hepatic diseases was higher in the non-prolonged ICU-LOS group,

\begin{tabular}{|c|c|c|c|}
\hline \multicolumn{4}{|c|}{$\begin{array}{l}\text { Table 1. Characteristics of patient groups and admission } \\
\text { diagnosis }\end{array}$} \\
\hline Parameters & $\begin{array}{l}\text { ICU-LOS of } \\
\geq 14 \\
n=939(18.7 \%)\end{array}$ & $\begin{array}{l}\text { ICU-LOS }<14 \\
n=4083 \\
(81.3 \%)\end{array}$ & $p$ \\
\hline Age (year) & $59.78 \pm 19.55$ & $60.66 \pm 19.16$ & 0.210 \\
\hline $18-65$ & $502(53.5)$ & $2145(52.6)$ & 0.608 \\
\hline $65-74$ & $174(18.5)$ & $821(20.1)$ & 0.274 \\
\hline $75-84$ & $174(18.5)$ & $732(17.9)$ & 0.665 \\
\hline$\geq 85$ & $89(9.5)$ & $385(9.4)$ & 0.963 \\
\hline Gender & & & 0.298 \\
\hline Female & $390(41.5)$ & $1772(43.4)$ & \\
\hline Male & $549(58.5)$ & $2311(56.6)$ & \\
\hline $\begin{array}{l}\text { Body mass index } \\
\left(\mathrm{kg} / \mathrm{m}^{2}\right)\end{array}$ & $\begin{array}{l}26.12(24.22- \\
29.38)\end{array}$ & $\begin{array}{l}25.95(23.87- \\
29.29)\end{array}$ & 0.003 \\
\hline Comorbidity & $671(71.5)$ & 3075 (75.3) & 0.014 \\
\hline Hypertension & $327(34.8)$ & $1508(36.9)$ & 0.226 \\
\hline Diabetes & $189(20.1)$ & $925(22.7)$ & 0.093 \\
\hline $\begin{array}{l}\text { Cerebrovascular } \\
\text { disease }\end{array}$ & $69(7.3)$ & $288(7.1)$ & 0.751 \\
\hline CAD & $106(11.3)$ & $424(10.4)$ & 0.416 \\
\hline COPD & $106(11.3)$ & $574(14.1)$ & 0.025 \\
\hline CRF & $81(8.6)$ & $381(9.3)$ & 0.500 \\
\hline Malignancy & $78(8.3)$ & $536(13.1)$ & $<0.001$ \\
\hline Hepatic disease & $9(1.0)$ & $79(1.9)$ & 0.040 \\
\hline Psychiatric disorder & $20(2.1)$ & $84(2.1)$ & 0.888 \\
\hline Dementia & $35(3.7)$ & $173(4.2)$ & 0.480 \\
\hline Obesity & $214(22.8)$ & $790(19.3)$ & 0.017 \\
\hline Other & $95(10.1)$ & $390(9.6)$ & 0.597 \\
\hline \multicolumn{4}{|l|}{ Admission diagnosis } \\
\hline $\begin{array}{l}\text { Cerebrovascular } \\
\text { disease }\end{array}$ & $141(15.0)$ & $587(14.4)$ & 0.616 \\
\hline Cardiac & $56(6)$ & $227(5.6)$ & 0.628 \\
\hline Pulmonary & $159(16.9)$ & $454(11.1)$ & $<0.001$ \\
\hline Pneumonia & $96(10.2)$ & $252(6.2)$ & $<0.001$ \\
\hline COPD & $48(5.1)$ & $134(3.3)$ & 0.007 \\
\hline Pulmonary, others & $15(1.6)$ & $68(1.7)$ & 0.883 \\
\hline Renal-metabolic & $44(4.7)$ & $234(5.7)$ & 0.207 \\
\hline Hepatic cirrhosis & $1(0.1)$ & $54(1.3)$ & $<0.001^{\star}$ \\
\hline Trauma & $153(16.3)$ & $399(9.8)$ & $<0.001$ \\
\hline Sepsis & $245(26.1)$ & $871(21.3)$ & 0.002 \\
\hline Pneumosepsis & $46(4.9)$ & $180(4.4)$ & 0.513 \\
\hline $\begin{array}{l}\text { Intra-abdominal } \\
\text { sepsis }\end{array}$ & $116(12.4)$ & 405 (9.9) & 0.027 \\
\hline Urosepsis & $22(2.3)$ & $79(1.9)$ & 0.422 \\
\hline Sepsis, other & $61(6.5)$ & $207(5.1)$ & 0.080 \\
\hline Malignancy & $44(4.7)$ & $325(8.0)$ & $<0.001$ \\
\hline Postoperative & $31(3.3)$ & $471(11.5)$ & $<0.001$ \\
\hline Intoxication & $13(1.4)$ & $162(4.0)$ & $<0.001$ \\
\hline GIB-hemorrhage & $19(2.0)$ & $123(3.0)$ & 0.099 \\
\hline Others & $33(3.5)$ & $176(4.3)$ & 0.271 \\
\hline
\end{tabular}


and the prevalence of obesity was higher in the prolonged ICU-LOS group $(p<0.05)$. The BMI values were 26.12 (24.2229.38) in the prolonged ICU-LOS group and 25.95 (23.87$29.29)$ in the non-prolonged ICU-LOS group $(p<0.05)$. The frequency of any other comorbid diseases was not significantly different between the groups. In both groups, the most common diagnosis on ICU admission was sepsis. Furthermore, a diagnosis of sepsis $(n=245 ; 26.1 \%)$ was more common in the prolonged ICU-LOS group than in the nonprolonged ICU-LOS group $(n=871 ; 21.3 \%)(p<0.05)$. Although the most common sepsis source was intra-abdominal sepsis in both groups, intra-abdominal sepsis was more common in the prolonged ICU-LOS group $(p<0.05)$. While pulmonary diseases $(n=96 ; 10.2 \%)$ and trauma $(n=153 ; 16.3 \%)$ were more common in the prolonged ICU-LOS group (due to COPD, pneumonia, and other causes), malignancy ( $n=325$; $8.0 \%)$, intoxication $(n=162,4.0 \%)$, hepatic diseases $(n=54$; $1.3 \%$ ), and postoperative follow-up $(n=471 ; 11.5 \%)$ were more common in the prolonged ICU-LOS group $(p<0.05)$ (Table 1).

The scores of the patients calculated during ICU admission, interventions, and treatments are shown in Table 2. APACHE II, APACHE IV, simplified acute physiology (SAPS) III, sequential organ failure assessment, and therapeutic intervention scoring system 28 scores were higher in the prolonged ICU-LOS group, whereas GCS and richmond agitation and sedation scale scores were lower $(p<0.001)$. Arterial and central venous catheterization was performed more frequently in the prolonged ICU-LOS group. MV and dialysis were more needed and the rate of tracheostomy was higher in the prolonged ICU-LOS group than in the non-prolonged ICU-LOS group $(p<0.001)$. The rates of using antibiotics, total parenteral nutrition (TPN), and vasoactive drugs were higher in the prolonged ICU-LOS group $(p<0.001)$. The average daily energy amounts given in the ICU of both groups were comparable $(p>0.05)$. The frequency of pressure sores and AKI was higher in the prolonged ICU-LOS group than in the non-prolonged ICULOS group $(p<0.001)$.

\section{MV and Blood Gas Parameters}

Patients with prolonged ICU-LOS needed mechanical ventilator support more frequently. While 61.8\% (2525) of the patients in the non-prolonged ICU-LOS group needed mechanical ventilator support, this rate increased to $97.4 \%$ (915) in the prolonged ICU-LOS group $(p<0.001)$. The duration of MV was longer in the prolonged ICU-LOS group [20.3 (14.9-29.2)] than in the non-prolonged ICU-LOS group [3.4 (1.7-6.2)] ( $p>0.001)$. Although the proportion of patients with prolonged ICU-LOS was $18.7 \%$, they consumed $66.3 \%$

\begin{tabular}{llll}
\hline \multicolumn{4}{l}{ Table 2. Scores, interventions, and treatments during ICU-LOS } \\
\hline Parameters & $\begin{array}{l}\text { ICU-LOS of } \geq 14 \\
\mathrm{n}=939(18.7 \%)\end{array}$ & $\begin{array}{l}\text { ICU-LOS }<14 \\
\mathrm{n}=4083(81.3 \%)\end{array}$ & $\mathrm{p}$ \\
\hline APACHE II & $24(19-29)$ & $19(12-27)$ & $<0.001$ \\
\hline APACHE IV & $85(64-107)$ & $71(49-100)$ & $<0.001$ \\
\hline SAPS III & $47(39-53)$ & $42(33-53)$ & $<0.001$ \\
\hline SOFA & $7(5-9)$ & $5(2-9)$ & $<0.001$ \\
\hline TISS & $22(17-27)$ & $19(15-24)$ & $<0.001$ \\
\hline GCS & $10(8-13)$ & $12(7-15)$ & $<0.001$ \\
\hline RASS & $-2[-4-(-1)]$ & $-1(-3-0)$ & $<0.001$ \\
\hline
\end{tabular}

\section{Interventions}

\begin{tabular}{|c|c|c|c|}
\hline Arterial catheter & $783(83.4)$ & $2704(66.2)$ & $<0.001$ \\
\hline Central catheter & $763(81.3)$ & $1783(43.7)$ & $<0.001$ \\
\hline MV & $915(97.4)$ & $2525(61.8)$ & $<0.001$ \\
\hline Tracheostomy & $617(65.7)$ & $284(7.0)$ & $<0.001$ \\
\hline Dialysis & $323(34.4)$ & $624(15.3)$ & $<0.001$ \\
\hline \multicolumn{4}{|l|}{ Treatments } \\
\hline $\begin{array}{l}\text { Nutrition } \\
\text { (kcal/day) }\end{array}$ & 1765 (1537-2089) & $\begin{array}{l}1752 \text { (1523- } \\
2039)\end{array}$ & 0.135 \\
\hline TPN & $582(62.0)$ & $1218(29.8)$ & $<0.001$ \\
\hline Antibiotics & 938 (99.9) & 3355 (78.2) & $<0.001$ \\
\hline $\begin{array}{l}\text { Vasoactive } \\
\text { agents }\end{array}$ & $730(77.7)$ & $2102(51.5)$ & $<0.001$ \\
\hline \multicolumn{4}{|l|}{ Complications } \\
\hline AKI & $699(74.4)$ & $2610(63.9)$ & $<0.001$ \\
\hline Pressure sores & $221(23.5)$ & $171(4.2)$ & $<0.001$ \\
\hline MV (day) & $20.3(14.9-29.2)$ & $3.4(1.7-6.3)$ & $<0.001$ \\
\hline LOS ICU (day) & $23.6(17.9-32.9)$ & $3.6(1.8-6.5)$ & $<0.001$ \\
\hline 28-day mortality & $248(26.4)$ & $1219(29.9)$ & 0.036 \\
\hline ICU mortality & $376(40.0)$ & $1219(29.9)$ & $<0.001$ \\
\hline \multicolumn{4}{|c|}{$\begin{array}{l}\text { APACHE: Acute physiology and chronic health evaluation, SAPS: Simplified } \\
\text { acute physiology, SOFA: Sequential organ failure assessment, TISS: } \\
\text { Therapeutic intervention scoring system, GCS: Glasgow coma score, RASS: } \\
\text { Richmond agitation and sedation scale, MV: Mechanical ventilation, TPN: } \\
\text { Total parenteral nutrition, AKI: Acute kidney injury, LOS: Length of stay, } \\
\text { ICU: Intensive care unit }\end{array}$} \\
\hline
\end{tabular}

of all mechanical ventilator days. When the mechanical ventilator parameters were examined, the positive endexpiratory pressure $[6.6(5.6-7.4)]$, peak pressure [14.8 (13.2-16.6)], and minute respiratory rate [19 (17-21)] values in the prolonged ICU-LOS group were higher, and work of breathing ventilator, pulmonary compliance, and tidal volumes were comparable. The mechanical power value was higher in the prolonged ICU-LOS group [9.72 (8.54-11.54)] than in the non-prolonged ICU-LOS group [8.85 (7.42-10.88)]. Partial pressure of carbon dioxide and bicarbonate levels 
were higher and lactate levels were lower in the prolonged ICU-LOS group when blood gas results were compared between the groups. Moreover, $\mathrm{pH}$ and $\mathrm{PO}_{2}$ values were comparable. Considering other laboratory parameters,

Table 3. Mechanical ventilator values and blood parameters of the patients during ICU follow-up

\begin{tabular}{|c|c|c|c|}
\hline Parameters & $\begin{array}{l}\text { ICU-LOS of } \geq 14 \\
n=939(18.7 \%)\end{array}$ & $\begin{array}{l}\text { ICU-LOS }<14 \\
n=4083(81.3 \%)\end{array}$ & $\mathrm{p}$ \\
\hline \multicolumn{4}{|c|}{ Mechanical ventilation } \\
\hline $\mathrm{FiO}_{2}(\%)$ & $43(40-46)$ & $44(40-49)$ & 0.063 \\
\hline PEEP $\left(\mathrm{cm} \mathrm{H}_{2} \mathrm{O}\right)$ & $6.6(5.6-7.4)$ & $6.0(5.1-6.7)$ & $<0.001$ \\
\hline \multicolumn{4}{|l|}{$P$ peak $(\mathrm{cm}$} \\
\hline Tidal volume & $492(439-556)$ & $499(444-559)$ & 0.455 \\
\hline $\begin{array}{l}\text { Tidal volume } \\
(\mathrm{mL} / \mathrm{kg})\end{array}$ & $6.83(6.17-7.60)$ & $6.80(6.08-7.60)$ & 0.344 \\
\hline $\begin{array}{l}\text { Respiratory rate } \\
\text { (min) }\end{array}$ & $19(17-21)$ & $17(15-20)$ & $<0.001$ \\
\hline $\begin{array}{l}\text { Compliance } \\
\left(\mathrm{mL} / \mathrm{cm} \mathrm{H}_{2} \mathrm{O}\right)\end{array}$ & $37.0(30.1-46.0)$ & $37.6(30.9-46.8)$ & 0.068 \\
\hline WOBv (j/L) & $1.13(0.99-1.26)$ & $1.12(0.98-1.30)$ & 0.134 \\
\hline $\begin{array}{l}\text { Mechanical } \\
\text { power }(\mathrm{J} / \mathrm{min})\end{array}$ & $9.72(8.54-11.54)$ & 8.85 (7.42-10.88) & $<0.001$ \\
\hline \multicolumn{4}{|l|}{ Blood gas } \\
\hline $\mathrm{PH}$ & $7.40(7.36-7.44)$ & $7.40(7.35-7.44)$ & $<0.092$ \\
\hline $\mathrm{PO}_{2}(\mathrm{~mm} \mathrm{Hg})$ & 89.5 (72.1-104.9) & $85.5(61.2-108.6)$ & 0.400 \\
\hline $\mathrm{PCO}_{2}(\mathrm{~mm} \mathrm{Hg})$ & $44.6(40.1-51.4)$ & $40.6(36.1-46.0)$ & $<0.001$ \\
\hline $\mathrm{HCO}_{3}(\mathrm{mEq} / \mathrm{L})$ & $26.7(24.2-30.0)$ & $24.4(21.2-27.1)$ & $<0.001$ \\
\hline $\begin{array}{l}\text { Lactate } \\
(\mathrm{mmol} / \mathrm{L})\end{array}$ & $1.61(1.33-2.14)$ & $1.87(1.36-3.35)$ & $<0.001$ \\
\hline \multicolumn{4}{|l|}{ Laboratory } \\
\hline Glucose (mg/dL) & $146(126-178)$ & $141(117-178)$ & $<0.001$ \\
\hline $\begin{array}{l}\text { Hemoglobin } \\
(\mathrm{g} / \mathrm{dL})\end{array}$ & $10.5(8.9-12.5)$ & $10.8(9.2-12.8)$ & 0.140 \\
\hline Hematocrit (\%) & $33.0(27.6-39.0)$ & $33.5(28.4-38.7)$ & 0.231 \\
\hline Platelet (x10\%/L) & $216(152-295)$ & $218(157-293)$ & 0.971 \\
\hline $\begin{array}{l}\text { White blood } \\
\text { cell (x10\%/L) }\end{array}$ & $12.7(9.5-16.8)$ & $13.0(10.4-16.2)$ & 0.284 \\
\hline $\begin{array}{l}\text { Procalcitonin } \\
(\mu \mathrm{g} / \mathrm{L})\end{array}$ & $1.03(0.40-5.07)$ & $0.82(0.35-3.98)$ & 0.026 \\
\hline INR & $1.20(1.09-1.38)$ & $1.17(1.06-1.41)$ & 0.045 \\
\hline APTT (sec) & $36.6(28.9-46.0)$ & $33.3(27.1-43.3)$ & $<0.001$ \\
\hline \multicolumn{4}{|c|}{ 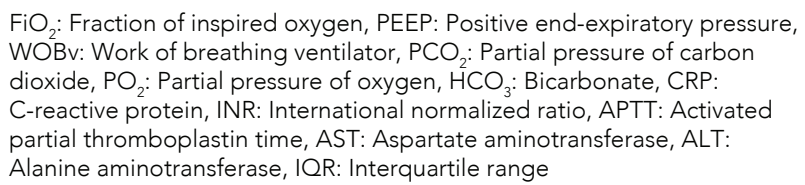 } \\
\hline
\end{tabular}

blood glucose and procalcitonin levels were higher in the prolonged ICU-LOS group. Hemoglobin, hematocrit, platelet, and white blood cell counts were comparable between the groups. International normalized ratio and activated partial thromboplastin time were increased in the prolonged ICU-LOS group (Table 3).

\section{LOS in the ICU and Mortality}

The ICU-LOS in the prolonged ICU-LOS group was 23.6 (17.9-32.9) days and that in the non-prolonged ICU-LOS group was 3.6 (1.8-6.5) days. Although only $18.7 \%(n=939)$ of the patients had ICU-LOS $\geq 14$ days, they consumed $59.7 \%$ of the total hospitalization days. The 28 -day mortality rate was $26.4 \%(n=248)$ in the prolonged ICU-LOS group and $29.9 \%(n=1219)$ in the non-prolonged ICU-LOS group $(p<0.05)$. Despite the lower 28 -day mortality in the prolonged ICU-LOS group, ICU mortality was higher in the prolonged ICU-LOS group ( $n=376 ; 40 \%)$ than in the non-prolonged ICU-LOS group ( $n=1,219 ; 29.9 \%$ ) (Table 2). In the subgroup analysis performed according to the admission diagnoses of the patients, the mortality rate in the prolonged ICU-LOS group was higher in patients followed up with the diagnoses of pulmonary diseases, sepsis, malignancy, postoperative follow-up, intoxication, and gastrointestinal bleeding $(p<0.05)$. The mortality rate in other admission diagnoses was not different between the groups (Table 4). The logistic regression model created to determine the factors associated with prolonged ICU-LOS found that the development of AKI in the ICU increased the probability of prolonged ICU-LOS by 1.8 times (OR: 1,807; $95 \% \mathrm{Cl}: 1,434-2,277)$, development of pressure sores by 3.5 times (OR: 3,572; 95\% Cl: 2,663-4.792), and TPN use by 2 times (OR: 2,014; $95 \% \mathrm{Cl}: 1,639-2,475)(p<0.001)$. In addition, the increase in BMI was associated with prolonged ICU-LOS (OR: 1,015; 95\% Cl: 1,001-1,031). Additionally, a one-unit increase in mechanical power increased the probability of prolonged ICU-LOS by $4.1 \%$ (OR: 1,$041 ; 95 \% \mathrm{Cl}$ : 1,0021,082). Patient age, APACHE II score, pulmonary compliance values, and need for vasoactive agents were not associated with prolonged ICU-LOS (Table 5).

\section{DISCUSSION}

This study, which aimed to determine the factors associated with prolonged ICU hospitalization, determined that increased BMI, TPN use, AKI, and pressure ulcer development were associated with prolonged ICU. In addition, the increase in mechanical power in patients who were intubated increased the possibility of prolonged $I C U$, and pulmonary compliance was not associated with prolonged ICU. Moreover, patient age, APACHE II score, 
Table 4. Mortality rates of the groups according to the diagnosis upon ICU admission

\begin{tabular}{|c|c|c|c|}
\hline $\begin{array}{l}\text { Admission } \\
\text { diagnosis }\end{array}$ & $\begin{array}{l}\text { ICU-LOS of } \geq 14 \\
n=939(18.7 \%)\end{array}$ & $\begin{array}{l}\text { ICU-LOS<14 } \\
n=4083 \\
(81.3 \%)\end{array}$ & $p$ \\
\hline $\begin{array}{l}\text { Cerebrovascular } \\
\text { disease }\end{array}$ & $41(29.1)$ & $177(30.2)$ & 0.802 \\
\hline Cardiac & $22(39.3)$ & $98(43.2)$ & 0.598 \\
\hline Pulmonary & $65(40.9)$ & $136(30.0)$ & 0.012 \\
\hline Pneumonia & $41(42.7)$ & $89(35.3)$ & 0.203 \\
\hline COPD & $16(33.3)$ & $29(21.6)$ & 0.107 \\
\hline Pulmonary, Other & $8(53.3)$ & $18(26.5)$ & 0.042 \\
\hline Renal-metabolic & $21(47.7)$ & 84 (35.9) & 0.138 \\
\hline Hepatic cirrhosis & $0(0)$ & $29(53.7)$ & $0.286^{*}$ \\
\hline Trauma & $31(20.3)$ & $91(22.8)$ & 0.519 \\
\hline Sepsis & 127 (51.8) & $363(41.7)$ & 0.005 \\
\hline Pneumosepsis & $21(45.7)$ & $74(41.1)$ & 0.578 \\
\hline $\begin{array}{l}\text { Intra-abdominal } \\
\text { sepsis }\end{array}$ & $56(48.3)$ & $165(40.7)$ & 0.148 \\
\hline Urosepsis & $11(50)$ & $17(21.5)$ & 0.008 \\
\hline Sepsis, other & 39 (63.9) & 107 (51.7) & 0.091 \\
\hline Malignancy & $24(54.5)$ & $85(26.2)$ & $<0.001$ \\
\hline Postoperative & $16(51.7)$ & $54(11.5)$ & $<0.001$ \\
\hline Intoxication & $6(46.2)$ & $17(10.5)$ & $<0.001$ \\
\hline GIB-hemorrhage & $15(78.9)$ & $53(43.1)$ & 0.004 \\
\hline Other & $8(24.2)$ & $32(18.2)$ & 0.417 \\
\hline 28-day mortality & $248(26.4)$ & 1219 (29.9) & 0.036 \\
\hline ICU mortality & $376(40.0)$ & 1219 (29.9) & $<0.001$ \\
\hline
\end{tabular}

COPD: Chronic obstructive pulmonary disease, GIB: Gastrointestinal bleeding, *Fisher's Exact test

Table 5. Parameters associated with prolonged ICU-LOS

\begin{tabular}{llll}
\hline Parameters & OR & $95 \% \mathrm{Cl}$ & P-value \\
\hline Age & 0.995 & $0.989-1.000$ & 0.055 \\
\hline Body mass index & 1.015 & $1.001-1.031$ & 0.036 \\
\hline APACHE II & 0.990 & $0.978-1.004$ & 0.156 \\
\hline AKI & 1.807 & $1.434-2.277$ & $<0.001$ \\
\hline Pressure sores & 3.572 & $2.663-4.792$ & $<0.001$ \\
\hline TPN & 2.014 & $1.639-2.475$ & $<0.001$ \\
\hline Vasoactive agents & 0.977 & $0.749-1.274$ & 0.861 \\
\hline Pulmoner compliance & 0.998 & $0.990-1.005$ & 0.525 \\
\hline Mechanical power & 1.041 & $1.002-1.082$ & 0.040 \\
\hline
\end{tabular}

APACHE: Acute physiology and chronic health evaluation, AKI: Acute kidney injury, TPN: Total parenteral nutrition and use of vasoactive agents were not associated with prolonged ICU-LOS. The rate of prolonged ICU-LOS was higher in patients diagnosed with sepsis and pulmonary diseases.

The increase in MV application, hemodynamic support, and organ support systems together with the developing technology in the ICU has enabled more patients to recover from acute critical illnesses (7). Decreased mortality in the acute period has led to the formation of a patient population that remains dependent on MV and other supportive treatments applied in the ICU for a long time. Despite the different definitions of long-term ICU-LOS in the literature, regardless of the definition employed, the proportion of this patient population was small. The small number of patients who stayed in the ICU for long periods tended to overuse resources disproportionately for their number. As a result of this study, although only $18.7 \%(n=939)$ of the patients has prolonged ICU-LOS, they consumed $66.3 \%$ of MV days and $59.7 \%$ of total hospitalization days. This finding is consistent with those of previous studies. In a similar study conducted in Canada, the average ICU-LOS was 4.74 days and $7.3 \%$ of the applications remained $>14$ days (14). In another study, $11 \%$ of the patients had prolonged ICU-LOS, but they consumed $45 \%$ of intensive care days and $56 \%$ of ventilation days (9). The modest number of patients with prolonged ICU-LOS consuming more than half of the MV days can be explained by the increased mechanical power in this patient group. Considering the potential causes of prolonged ICU-LOS, the suppression of the immune system is considered common after trauma, sepsis, and other serious diseases, and this immune dysfunction plays a role in patients who stayed in the ICU for a long time (15). Another study suggested endocrinopathy acquired in the ICU (16). In another study, early nutritional needs of patients in the ICU were given sufficient attention, and the resulting iatrogenic malnutrition may lead to long-term hospitalization (17).

In line with the results of this study, which determined that prolonged ICU-LOS is more common in patients hospitalized in the ICU with the diagnosis of pulmonary diseases and sepsis, other studies have reported that long-term hospitalization is associated with sepsis and acute respiratory failure requiring MV $(9,18,19)$. Pulmonary diseases and sepsis increased proinflammatory activity that can lead to organ failures, neuromuscular weakness, and dysfunction, leading to prolonged hospitalization (20). This finding indicates that early treatment of pulmonary diseases that cause sepsis and acute respiratory failure is an important goal for the prevention of long-term hospitalization. Treatments and practices such as early 
resuscitation, conservative fluid management after the shock period, early mobilization, low tidal volume, and avoidance of excessive sedation, which can prevent early organ damage in the course of critical illness, may help the clinician to prevent long-term hospitalization (20-25). The present study also found that the usage rate of vasoactive drug was higher in the prolonged ICU-LOS group. However, vasoactive drug use was not associated with prolonged ICU-LOS. A similar study reported that vasoactive drug use and prolonged ICU-LOS were not associated (6). This is probably because patients who need vasopressors are in the more severe patient group and are more likely to die early after ICU admission.

In the present study, APACHE II, SAPS III, and other disease severity scores were higher in the prolonged ICU-LOS group, but they were not associated with prolonged ICULOS. Contrary to our results, a multicenter study, which was conducted with APACHE II, examined ICU-LOS for 10 months in 5,881 patients and found that patients with short ICU-LOS had high APACHE II scores (26). Another study found that patients with very high disease severity (APACHE $I I \geq 30$ ) had a short ICU-LOS because they died early in the ICU (18). Patients with low disease severity have relatively short ICU-LOS and are then discharged from the ICU, probably because they only need intensive care for a short time. By contrast, patients with very high disease severity have a shorter ICU-LOS because mortality develops in the early period. Considering the studies on SAPS III, which is another disease severity score, a study evaluated the SAPS III scores of the patients during admission to the ICU and found that patients with high SAPS III scores had a longer ICU-LOS (6). In another study, patients with a higher SAPS III scores stayed in the postoperative ICU for 3 more days (27). This situation can be explained by the high chronic disease burden of most of the patients with high SAPS III scores (6).

The present study also found that the increase in BMI and development of pressure sores were associated with prolonged ICU-LOS. Similar studies have reported that obesity increases ICU time, which is consistent with our results $(28,29)$. In a meta-analysis including 23 studies, a trend was found to increase ICU-LOS in patients who were obese (29). In another meta-analysis study including 14 studies, obesity was associated with increased ICU-LOS and MV time (28). Nursing care of patients who are obese is more difficult than those with normal weight because of the large body weight and large body surface area. Difficult position changes in these patients may cause pressure sores and skin lacerations. Disruption of the protective skin barrier may prolong ICU-LOS in patients who are obese by increasing complications such as infection or bleeding $(30,31)$.

Another finding of this study was that AKI development was associated with prolonged ICU-LOS of patients with critical illness. Our results are compatible with the literature. Previous studies have shown that AKI development is associated with prolonged ICU-LOS and increased morbidity, hospital costs, and worse outcomes in patients with critical illness $(32,33)$. Impairment of pulmonary dynamics due to hypervolemia, which is common with decreased pulmonary compliance in patients with $A K I$, may increase respiratory workload and prolong MV time (34). In the present study, another parameter related to prolonged ICU-LOS was TPN. Similarly, a previous study showed that TPN use prolonged ICU-LOS (35). TPN was associated with infectious complications due to hyperalimentation and hyperglycemia, which may explain its association with prolonged ICU-LOS $(36,37)$.

\section{Study Limitations}

In addition to its strengths, such as minimized data loss since the study data were obtained by the CDSS with electronic queries and all ICU processes were followed in our clinic, this study has some limitations. First, its singlecenter design prevents generalization of the results despite the diversity in the patient population. Second, given its retrospective nature, confounding factors may affect the results and increase bias risk. Third, data on long-term survival and functional outcomes of the patients could not be obtained. Fourth, since data on IV fluids and diuretic treatments given before the ICU follow-up could not be obtained, the weights measured in the ICU and urine volume of patients may have affected the BMI and AKI data. Fifth, comorbidities may have been underestimated because of deficiencies in patient's statement during anamnesis. Finally, the lack of a common consensus for the need for prolonged intensive care and various definitions in previous studies that accepted it as 10,14, and 21 days may lead to differences in results, where we determined the need for prolonged intensive care as $\geq 14$ days.

\section{CONCLUSION}

Patients who had prolonged ICU-LOS occupied $66.3 \%$ of MV days and $59.7 \%$ of total hospitalization days. The rate of prolonged ICU-LOS was higher in patients diagnosed with sepsis and pulmonary diseases. An increase in BMI, TPN use, AKI, and pressure ulcer development was associated with prolonged ICU. The increase in mechanical power increased the probability of prolonged ICU in patients who needed MV. Patient age, APACHE II score, and use 
of vasoactive agents were not associated with prolonged ICU-LOS. A full understanding of the factors associated with prolonged ICU-LOS will be achieved through prospective studies that will generalize well-designed results and randomize patients with prolonged ICU-LOS at the center of the study.

\section{ETHICS}

Ethics Committee Approval: The study were approved by the Bakırköy Dr. Sadi Konuk Training and Research Hospital of Local Ethics Committee (protocol code: 2021/405-decision number: 2021-16).

\section{Informed Consent: Retrospective study.}

\section{Authorship Contributions}

Surgical and Medical Practices: M.S.S., S.A., Concept: M.S.S., S.A., Design: M.S.S., S.A., Data Collection or Processing: M.S.S., S.A., Analysis or Interpretation: M.S.S., Literature Search: M.S.S., S.A., Writing: M.S.S., S.A.

Conflict of Interest: No conflict of interest was declared by the authors.

Financial Disclosure: The authors declared that this study received no financial support.

\section{REFERENCES}

1. Vincent $J \mathrm{~L}$, Singer $\mathrm{M}$. Critical care: advances and future perspectives. Lancet 2010;376:1354-61.

2. Angus DC, Shorr AF, White A, Dremsizov TT, Schmitz RJ, Kelley MA; Committee on Manpower for Pulmonary and Critical Care Societies (COMPACCS). Critical care delivery in the United States: distribution of services and compliance with Leapfrog recommendations. Crit Care Med 2006;34:1016-24.

3. Erickson SE, Martin GS, Davis JL, Matthay MA, Eisner MD; NIH NHLBI ARDS Network. Recent trends in acute lung injury mortality: 1996-2005. Crit Care Med 2009;37:1574-9.

4. Williams TA, Ho KM, Dobb GJ, Finn JC, Knuiman M, Webb SA; Royal Perth Hospital ICU Data Linkage Group. Effect of length of stay in intensive care unit on hospital and long-term mortality of critically ill adult patients. Br J Anaesth 2010;104:459-64.

5. Crozier TM, Pilcher DV, Bailey MJ, George C, Hart GK. Longstay patients in Australian and New Zealand intensive care units: demographics and outcomes. Crit Care Resusc 2007;9:327-33.

6. Zampieri FG, Colombari F, Lovatto Pastore CDB, Santoro C, Haib D, Ladeira JP. Factors associated with prolonged ICU stay: a retrospective analysis. Crit Care 2013;17(Suppl 3):P9.

7. Kıray G, Inal MT, Memiş D, Turan FN. Investigation of the Factors Affecting Prolonged Intensive Care Unit. J Turk Soc Intens Care 2020;18:84-90.

8. Laupland KB, Kirkpatrick AW, Kortbeek JB, Zuege DJ. Long-term mortality outcome associated with prolonged admission to the ICU. Chest 2006;129:954-9.

9. Arabi Y, Venkatesh S, Haddad S, Al Shimemeri A, Al Malik S. A prospective study of prolonged stay in the intensive care unit: predictors and impact on resource utilization. Int J Qual Health Care 2002;14:403-10.
10. Heyland DK, Konopad E, Noseworthy TW, Johnston R, Gafni A. Is it 'worthwhile' to continue treating patients with a prolonged stay $(>14$ days) in the ICU? An economic evaluation. Chest 1998;114:192-8.

11. Fakhry SM, Kercher KW, Rutledge R. Survival, quality of life, and charges in critically III surgical patients requiring prolonged ICU stays. J Trauma 1996;41:999-1007.

12. Gilio AE, Stape A, Pereira CR, Cardoso MF, Silva CV, Troster EJ. Risk factors for nosocomial infections in a critically ill pediatric population: a 25-month prospective cohort study. Infect Control Hosp Epidemiol 2000;21:340-2.

13. Sabaz MS, Asar S, Cukurova Z, Sabaz N, Doğan H, Sertcakacılar G. Effect of Delayed Admission to Intensive Care Units from the Emergency Department on the Mortality of Critically III Patients. Iran Red Crescent Med J 2020;22:e102425.

14. Wong DT, Gomez M, McGuire GP, Kavanagh B. Utilization of intensive care unit days in a Canadian medical-surgical intensive care unit. Crit Care Med 1999;27:1319-24.

15. Patera AC, Drewry AM, Chang K, Beiter ER, Osborne D, Hotchkiss RS. Frontline Science: Defects in immune function in patients with sepsis are associated with PD-1 or PD-L1 expression and can be restored by antibodies targeting PD-1 or PD-L1. J Leukoc Biol 2016;100:1239-54.

16. Van den Berghe GH. Acute and prolonged critical illness are two distinct neuroendocrine paradigms. Verh K Acad Geneeskd Belg 1998;60:487-518.

17. Bear DE, Wandrag L, Merriweather JL, Connolly B, Hart N, Grocott MPW; Enhanced Recovery After Critical Illness Programme Group (ERACIP) investigators. The role of nutritional support in the physical and functional recovery of critically ill patients: a narrative review. Crit Care 2017;21:226.

18. Higgins TL, McGee WT, Steingrub JS, Rapoport J, Lemeshow S, Teres D. Early indicators of prolonged intensive care unit stay: impact of illness severity, physician staffing, and pre-intensive care unit length of stay. Crit Care Med 2003;31:45-51.

19. Estenssoro E, González F, Laffaire E, Canales H, Sáenz G, Reina R, et al. Shock on admission day is the best predictor of prolonged mechanical ventilation in the ICU. Chest 2005;127:598-603.

20. Villar J, Blanco J, Zhang H, Slutsky AS. Ventilator-induced lung injury and sepsis: two sides of the same coin? Minerva Anestesiol 2011;77:647-53.

21. ProCESS Investigators, Yealy DM, Kellum JA, Huang DT, Barnato $A E$, Weissfeld LA, Pike $F$, et al. A randomized trial of protocolbased care for early septic shock. N Engl J Med 2014;370:1683-93.

22. National Heart, Lung, and Blood Institute Acute Respiratory Distress Syndrome (ARDS) Clinical Trials Network, Wiedemann HP, Wheeler AP, Bernard GR, Thompson BT, Hayden D, deBoisblanc $B$, et al. Comparison of two fluid-management strategies in acute lung injury. N Engl J Med 2006;354:2564-75.

23. Schweickert WD, Pohlman MC, Pohlman AS, Nigos C, Pawlik AJ, Esbrook CL, et al. Early physical and occupational therapy in mechanically ventilated, critically ill patients: a randomised controlled trial. Lancet 2009;373:1874-82.

24. Acute Respiratory Distress Syndrome Network, Brower RG, Matthay MA, Morris A, Schoenfeld D, Thompson BT, Wheeler A. Ventilation with lower tidal volumes as compared with traditional tidal volumes for acute lung injury and the acute respiratory distress syndrome. N Engl J Med 2000;342:1301-8.

25. Girard TD, Kress JP, Fuchs BD, Thomason JW, Schweickert WD, Pun BT, et al. Efficacy and safety of a paired sedation and ventilator weaning protocol for mechanically ventilated patients in intensive care (Awakening and Breathing Controlled trial): a randomised controlled trial. Lancet 2008;371:126-34. 
26. Martin CM, Hill AD, Burns K, Chen LM. Characteristics and outcomes for critically ill patients with prolonged intensive care unit stays. Crit Care Med 2005;33:1922-7.

27. Abelha FJ, Castro MA, Landeiro NM, Neves AM, Santos CC Mortalidade e o tempo de internação em uma unidade de terapia intensiva cirúrgica [Mortality and length of stay in a surgical intensive care unit.]. Rev Bras Anestesiol 2006;56:34-45.

28. Akinnusi ME, Pineda LA, El Solh AA. Effect of obesity on intensive care morbidity and mortality: a meta-analysis. Crit Care Med 2008;36:151-8.

29. Oliveros H, Villamor E. Obesity and mortality in critically ill adults: a systematic review and meta-analysis. Obesity (Silver Spring) 2008;16:515-21.

30. Winkelman C, Maloney B, Kloos J. The impact of obesity on critical care resource use and outcomes. Crit Care Nurs Clin North Am 2009;21:403-22.

31. Joffe A, Wood K. Obesity in critical care. Curr Opin Anaesthesiol 2007;20:113-8.

32. Abdel-Rahman EM, Okusa MD. Effects of aging on renal function and regenerative capacity. Nephron Clin Pract 2014;127:15-20.
33. Sileanu FE, Murugan R, Lucko N, Clermont G, Kane-Gill SL, Handler $\mathrm{SM}$, et al. AKI in low-risk versus high-risk patients in intensive care. Clin J Am Soc Nephrol 2015;10:187-96.

34. Nguyen YL, Angus DC, Boumendil A, Guidet B. The challenge of admitting the very elderly to intensive care. Ann Intensive Care $2011 ; 1: 29$

35. Elke G, van Zanten AR, Lemieux M, McCall M, Jeejeebhoy KN, Kott $M$, et al. Enteral versus parenteral nutrition in critically ill patients: an updated systematic review and meta-analysis of randomized controlled trials. Crit Care 2016;20:117.

36. Gramlich L, Kichian K, Pinilla J, Rodych NJ, Dhaliwal R, Heyland DK. Does enteral nutrition compared to parenteral nutrition result in better outcomes in critically ill adult patients? A systematic review of the literature. Nutrition 2004;20:843-8.

37. Peter JV, Moran JL, Phillips-Hughes J. A metaanalysis of treatment outcomes of early enteral versus early parenteral nutrition in hospitalized patients. Crit Care Med 2005;33:213-20; discussion 260-1. 